\title{
Population dynamics: seasonal variation of phytoplankton functional groups in Brazilian reservoirs (Billings and Guarapiranga, São Paulo)
}

\author{
Gemelgo, MCP. ${ }^{\mathrm{a}}$, Mucci, JLN. ${ }^{\mathrm{b} *}$ and Navas-Pereira, D. ${ }^{\mathrm{b}}$ \\ ${ }^{a}$ Departamento de Microbiologia, Instituto de Ciências Biomédicas, \\ Universidade de São Paulo - USP, \\ Av. Prof. Lineu Prestes, 1374, CEP 05508-900, São Paulo, SP, Brazil \\ bDepartamento de Saúde Ambiental, Faculdade de Saúde Pública, \\ Universidade de São Paulo - USP, \\ Av. Dr. Arnaldo, 715, $1^{\circ}$ andar, CEP 01246-904, São Paulo, SP, Brazil \\ *e-mail: jlnmucci@usp.br
}

Received March 28, 2008 - Accepted August 7, 2008 -Distributed November 30, 2009

(With 6 figures)

\begin{abstract}
Phytoplankton may function as a "sensor" of changes in aquatic environment and responds rapidly to such changes. In freshwaters, coexistence of species that have similar ecological requirements and show the same environmental requirements frequently occurs; such species groups are named functional groups. The use of phytoplankton functional groups to evaluate these changes has proven to be very useful and effective. Thus, the aim of this study was to evaluate the occurrence of functional groups of phytoplankton in two reservoirs (Billings and Guarapiranga) that supply water to millions of people in São Paulo city Metropolitan Area, southeastern Brazil. Surface water samples were collected monthly and physical, chemical and biological (quantitative and qualitative analyses of the phytoplankton) were performed. The highest biovolume $\left(\mathrm{mm}^{3} . \mathrm{L}^{-1}\right)$ of the descriptor species and functional groups were represented respectively by Anabaena circinalis Rabenh. (H1), Microcystis aeruginosa (Kützing) Kützing $\left(\mathrm{L}_{\mathrm{M}} / \mathrm{M}\right)$ and Mougeotia sp. (T) in the Guarapiranga reservoir and Cylindrospermopsis raciborskii (Wolosz.) Seen. and Subba Raju $\left(\mathrm{S}_{\mathrm{N}}\right)$, Microcystis aeruginosa and M. panniformis Komárek et al. $\left(\mathrm{L}_{\mathrm{M}} / \mathrm{M}\right)$, Planktothrix agardhii (Gom.) Anagn. and Komárek and P. cf. clathrata (Skuja) Anagn. and Komárek (S1) in the Billings reservoir. The environmental factors that most influenced the phytoplankton dynamics were water temperature, euphotic zone, turbidity, conductivity, $\mathrm{pH}$, dissolved oxygen, nitrate and total phosphorous.
\end{abstract}

Keywords: phytoplankton, descriptor species, functional groups, water supply.

\section{Dinâmica populacional: variação sazonal dos grupos funcionais fitoplanctônicos em reservatórios brasileiros (Billings e Guarapiranga, São Paulo)}

\begin{abstract}
Resumo
A comunidade fitoplanctônica pode funcionar como sensor das variações do ambiente aquático respondendo rapidamente as essas alterações. Em sistemas aquáticos continentais é comum a coexistência de espécies que possuem as mesmas necessidades ecológicas e apresentam as mesmas tolerâncias ambientais, tais grupos de espécies fitoplanctônicas são denominados grupos funcionais. O uso de grupos funcionais fitoplanctônicos para avaliar tais alterações tem se mostrado muito útil e eficaz. Assim, o objetivo do estudo foi avaliar a ocorrência de grupos funcionais fitoplanctônicos em dois reservatórios (Billings e Guarapiranga) que suprem de água milhões de pessoas na Região Metropolitana de São Paulo, Sudeste do Brasil. As amostras foram coletadas mensalmente na superfície da coluna d'água e foram analisadas as variáveis físicas, químicas e biológicas (análises qualitativa e quantitativa do fitoplâncton). Os maiores valores de biovolume $\left(\mathrm{mm}^{3} \cdot \mathrm{L}^{-1}\right)$ das espécies descritoras e grupos funcionais foram representados por Anabaena circinalis (H1), Microcystis aeruginosa $\left(\mathrm{L}_{\mathrm{M}} / \mathrm{M}\right)$ e Mougeotia sp. (T) no Reservatório Guarapiranga e por Cylindrospermopsis raciborskii $\left(\mathrm{S}_{\mathrm{N}}\right)$, Microcystis aeruginosa e M. panniformis $\left(\mathrm{L}_{\mathrm{M}} / \mathrm{M}\right)$, Planktothrix agardhii e $P$. cf. clathrata (S1) no Reservatório Billings. Os principais fatores ambientais que interferiram na dinâmica do fitoplâncton foram: temperatura da água, zona eufótica, turbidez, condutividade, $\mathrm{pH}$, oxigênio dissolvido, nitrato e fósforo total.
\end{abstract}

Palavras-chave: fitoplâncton, espécies descritoras, grupos funcionais, reservatórios de abastecimento. 


\section{Introduction}

The phytoplankton community may function as a "sensor" of changes in aquatic environments and responds rapidly to such changes. According to the frequency and intensity of these changes, qualitative and quantitative aspects of the biota can be modified, selecting species by means of competition mechanisms allowing the survival of species favoured by their adaptive strategies (Margalef, 1983; Reynolds, 1988).

High levels of nutrients - mainly phosphate and nitrogen compounds - in water, along with high light intensity, water temperature above $20{ }^{\circ} \mathrm{C}$ and $\mathrm{pH}$ values between 6 and 9 increase phytoplankton cell multiplication, leading to blooms (Zagatto et al., 1997).

Changes in phytoplankton composition and abundance can be the result of environmental changes which may occur with variable frequency and intensity, thus causing changes in qualitative and quantitative aspects of the biota, showing selected species through competition processes that favour them (Calijuri, 1999).

The process to optimise energy application by species is named survival strategy (Grime, 1979; Reynolds, 1988). Survival strategies can be considered as groups of morphological, physiological, reproductive and behavioural characteristics that evolved among species and populations, leading to a more adequate response to different environmental conditions. (Grime, 1979).

The word association is used by terrestrial vegetation ecologists to group species which have similar responses to a set of environmental conditions. In freshwaters, coexistence of species that have similar ecological requirements and show the same environmental requirements frequently occurs and such species groups are named functional groups (Reynolds, 1997; Reynolds et al., 2002; Padisák et al., 2006).

The application of the concept of phytoplankton functional groups in temperate regions has been used by several authors (Arauzo and Cobelas, 1994; Reynolds, 1997; Huszar et al., 2003; Padisäk et al., 2003). Reynolds et al. (2002) proposed a list of functional groups, based on their tolerances and sensitivities and on their occurrence in different environmental conditions. The authors included 31 groups that gathered species belonging to distinct classes, but with similar strategies that allowed their survival in specific environmental conditions. In tropical and subtropical regions, Reynolds et al. (2002) approach has been very seldom applied. Kruk et al. (2002) studied phytoplankton functional groups of a small urban lake in Montevideo, Uruguay and in Brazil, studies by Beyruth
(2000), Melo and Huszar (2000), Tucci (2002), Crossetti and Bicudo (2005), Lopes et al. (2005) and Borges et al. (2008) can be mentioned.

There is little research about the phytoplankton dynamics of the studied reservoirs: Souza et al. (1998) showed that, in a Billings reservoir branch, Chlorophyceae and Cyanobacteria were dominant throughout the studied period. Beyruth (2000) showed the relationship between physical and chemical parameters and phytoplankton associations in Guarapiranga reservoir, Chlorophyceae biomass being the best represented. Carvalho (2003) has studied the phytoplankton community of six water supply reservoirs in São Paulo state, to identify indicator species and biological indexes, among these reservoirs; Billings had 154 taxa, Cyanobacteria being dominant in all sampling seasons. Matsuzaki (2007) evaluated the sanitary aspects of Guarapiranga reservoir after the transposition of waters from the Taquecetuba branch of Billings reservoir, showing the high trophic indexes and dominance of Cyanobacteria in both reservoirs. Thus, it was supposed that there were significant differences between the phytoplankton of both reservoirs, due to environmental factors.

The use of phytoplankton functional groups to evaluate these changes has proven to be very useful and effective. Thus, the aim of this study was to evaluate the occurrence of functional groups in two reservoirs.

\section{Material and Methods}

The reservoirs studied herein, called Guarapiranga and Billings located in the city of São Paulo Metropolitan Area, southeastern Brazil (Table 1) have been submitted to intense human influence, especially in relation to the discharge of domestic, industrial and agricultural wastes, along with the removal of the surrounding vegetation (Carvalho, 2003). These reservoirs are used for the public water supply and recreation of three million people and supply hundreds of industries with water.

The Trophic State Index (TSI) adopted was that of Carlson (1977) adapted to tropical environments, as proposed by Lamparelli (2004). In this work, the TSI was calculated by simple arithmetic mean for the indexes of total phosphorus and chlorophyll- $a$, according to the equation:

$\mathrm{TSI}=[\mathrm{TSI}(\mathrm{TP})+\mathrm{TSI}(\mathrm{CL})] / 2$

where:

TSI $(\mathrm{TP})=10 .(6-(1.77-0.42 .(\ln \mathrm{TP}) / \ln 2))$

Table 1. General characteristics of the Guarapiranga and Billings reservoirs.

\begin{tabular}{lcc}
\hline & Guarapiranga & Billings \\
\hline Coordinates & $23^{\circ} 43^{\prime} \mathrm{S}$ and $46^{\circ} 32^{\prime} \mathrm{W}$ & $23^{\circ} 47^{\prime} \mathrm{S}$ and $46^{\circ} 40^{\prime} \mathrm{W}$ \\
Area & $33 \mathrm{~km}^{2}$ & $120 \mathrm{~km}^{2}$ \\
Maximum depth & $13 \mathrm{~m}$ & $18 \mathrm{~m}$ \\
Water retention time & 185 days & 720 days \\
\hline
\end{tabular}

Source: Beyruth et al. (1997); CETESB (1997, 2004) 
TSI $(C L)=10 .(6-((0.92-0.34 .(\ln C L) / \ln 2))$

$\mathrm{TP}=$ total phosphorus concentration in surface water $\left(\mu \mathrm{g} . \mathrm{L}^{-1}\right)$.

$\mathrm{CL}=$ total chlorophyll- $a$ concentration in surface water $\left(\mu \mathrm{g} . \mathrm{L}^{-1}\right)$.

$\ln =$ natural logarithmic

According to Lamparelli (2004), another trophic class was introduced between the eutrophic and hypereutrophic, this being named supereutrophic. Table 2 shows the new criteria for the evaluation of the trophic state of waters.

Surface water samples were collected monthly from February/2002 to January/2003. In each reservoir samples were taken from the catchment point of water for public supply. The variables studied were: water temperature, transparency (Secchi disk), euphotic zone evaluated by three times the depth where the Secchi disk disappears (Cole, 1994), turbidity (turbidimeter), dissolved oxygen (Oxygen meter OXI-197 WTW), pH, ammonium (NBR 10560, ABNT, 1988), nitrate $\left(4500 \mathrm{NO}_{3}\right.$, APHA, 1998), Nitrite (4500NO, APHA, 1998) total phosphorous (4500P, APHA, 1998) and chlorophyll- $a$ (CETESB, 1990).

Samples for the qualitative analyses of the phytoplankton were filtered with $20 \mu \mathrm{m}$ mesh plankton net, fixed with $4 \%$ formalin. The material was analysed under a binocular microscope the optical train of which was fitted with a light chamber, a measuring eyepiece and an epifluorescence device.

Cyanobacteria were identified according to Komárek and Anagnostidis (1989; 1999; 2005) and the other classes were classified according to Van den Hoek et al. (1995). The functional groups were evaluated according to the criteria established by Reynolds et al. (2002).

Samples for the quantitative analyses of the phytoplankton were collected with a Van Dorn bottle and preserved in a $1 \%$ acetic lugol solution. Counting was performed according to the Utermöhl method (1958), under a Carl Zeiss ${ }^{\circledR}$ inverted microscope with a magnification of 400 times. Counting was performed horizontally and vertically, and the minimum number of fields to be counted was determined by the curve of the species stabilisation graph, which was obtained from the new species added in each counted field.

Descriptor species were selected based on the density (org. $\mathrm{mL}^{-1}$ ). Those species that contributed with more

Table 2. Classification and TSI values for São Paulo State reservoirs.

\begin{tabular}{lcr}
\hline Trophic level & Classes & \multicolumn{1}{c}{ TSI } \\
\hline Ultraoligotrophic & 0.5 & $\leq 47$ \\
Oligotrophic & 1 & $47<$ TSI $\leq 52$ \\
Mesotrophic & 2 & $52<$ TSI $\leq 59$ \\
Eutrophic & 3 & $59<$ TSI $\leq 63$ \\
Supereutrophic & 4 & $63<$ TSI $\leq 67$ \\
Hypereutrophic & 5 & $>67$ \\
\hline
\end{tabular}

Source: Lamparelli (2004) than $1 \%$ of the annual total density of the community were considered as descriptors. For these taxa, the respective biovolumes were calculated.

The biovolume $\left(\mathrm{mm}^{3} \cdot \mathrm{L}^{-1}\right)$ was estimated by multiplying the density of each species by the mean volume of their cells. Biovolume was calculated based on geometric models, according to Edler (1979) and Hillebrand et al. (1999).

The results were statistically analysed by means of the Principal Component Analyses (PCA) and Canonical Correspondence Analyses (CCA). In these analyses the data matrix were transformed by ranging and $\log (\mathrm{x}+1)$ respectively. To transform the results and perform the analyses, FITOPAC (Shepherd, 1986) and PC-ORD version 3.1 for Windows (McCune and Mefford, 1997) software were used.

In the text, tables and graphs, the environmental variables were abbreviated as follows: Water temperature (WT), transparency (Transp), euphotic zone (Euphz), turbidity (Turb), Dissolved Oxygen (DO), conductivity (Cond), ammonia $\left(\mathrm{NH}_{4}\right)$, nitrate $\left(\mathrm{NO}_{3}\right)$, nitrite $\left(\mathrm{NO}_{2}\right)$ and total phosphorous (TP).

\section{Results}

The Trophic State Index applied was calculated through the simple arithmetic mean of the total phosphorus and chlorophyll- $a$ indexes. The results (Table 3 and Figure 1) showed the Billings reservoir as supereutrophic in February/2002 and hypereutrophic in the other months; furthermore, Guarapiranga reservoir ranged from eutrophic to hypereutrophic.

\subsection{Abiotic variables}

The mean water temperature values in both reservoirs were almost the same, ranging from 19 to $29^{\circ} \mathrm{C}$. Rainfall monthly values were lower than $270 \mathrm{~mm}$ in both reservoirs. Transparency showed little variation, ranging from $0.4 \mathrm{~m}$ in Billings to $1.6 \mathrm{~m}$ in Guarapiranga. Turbidity and conductivity showed higher values in Billings; $\mathrm{pH}$ and

Table 3. Trophic State Index (TSI) of Billings and Guarapiranga reservoirs.

\begin{tabular}{lcc}
\hline Sampling date & Billings & Guarapiranga \\
\hline February/2002 & 66.04 & 66.91 \\
March/2002 & 69.26 & 61.77 \\
April/2002 & 67.76 & 64.60 \\
May/2002 & 67.46 & 64.44 \\
June/2002 & 68.76 & 64.19 \\
July/2002 & 68.54 & 64.15 \\
August/2002 & 69.50 & 62.65 \\
September/2002 & 68.56 & 63.30 \\
October/2002 & 69.40 & 61.65 \\
November/2002 & 69.40 & 67.17 \\
December/2002 & 70.14 & 63.02 \\
January/2003 & 70.49 & 63.57 \\
\hline
\end{tabular}


Trophic State Index

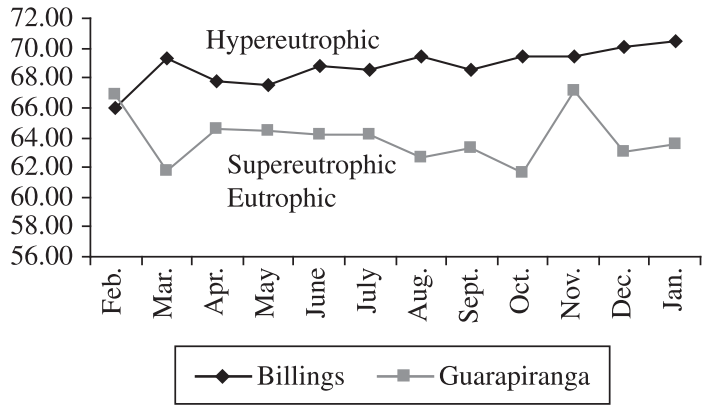

Figure 1. Monthly variation of Trophic State Index in Billings and Guarapiranga reservoirs.
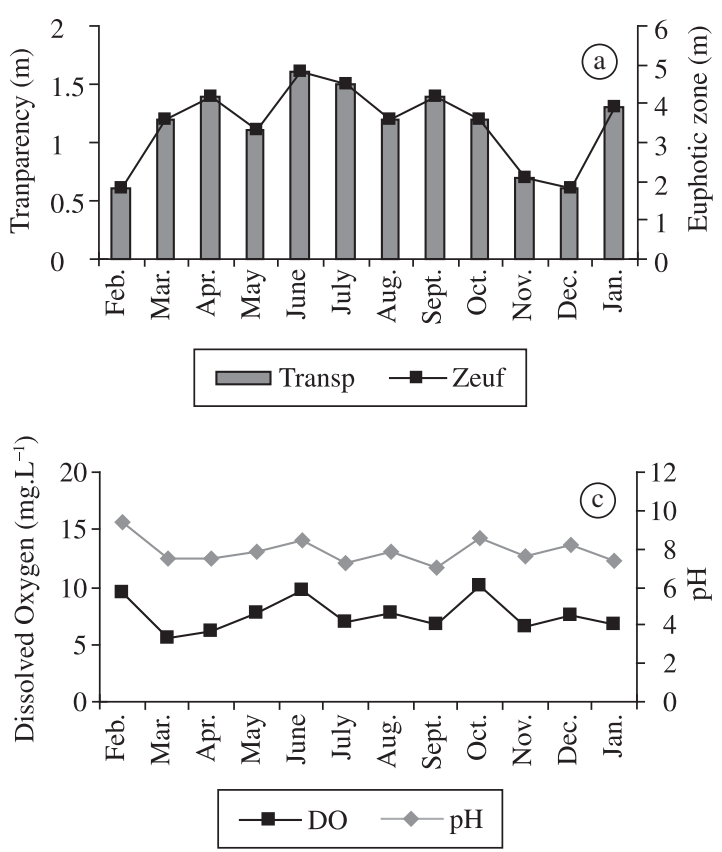

dissolved oxygen were almost the same in both reservoirs, being higher in June and October/2002 in Billings. Nutrients $\left(\mathrm{N}-\mathrm{NH}_{4}{ }_{4}, \mathrm{~N}-\mathrm{NO}_{3}^{-}, \mathrm{N}_{-} \mathrm{NO}_{2}{ }^{-}\right.$e TP) showed high values in both reservoirs. Monthly changes of the physical and chemical variables in Guarapiranga and Billings reservoirs can be seen in Figures 2 and 3.

Principal Components Analysis (PCA) showed that the most significant environmental variables were: water temperature, transparency, euphotic zone, turbidity, conductivity, $\mathrm{pH}$, dissolved oxygen, nitrate, nitrite and total phosphorous. PCA, when applied to both reservoirs studies herein, showed the two aquatic environments as two different units, grouping $67 \%$ of the total variability in the two first axes, thus accounting for a significant percentage of total variance of the data (Table 4, Figure 4). Axis 1 summarised the variability for both systems,
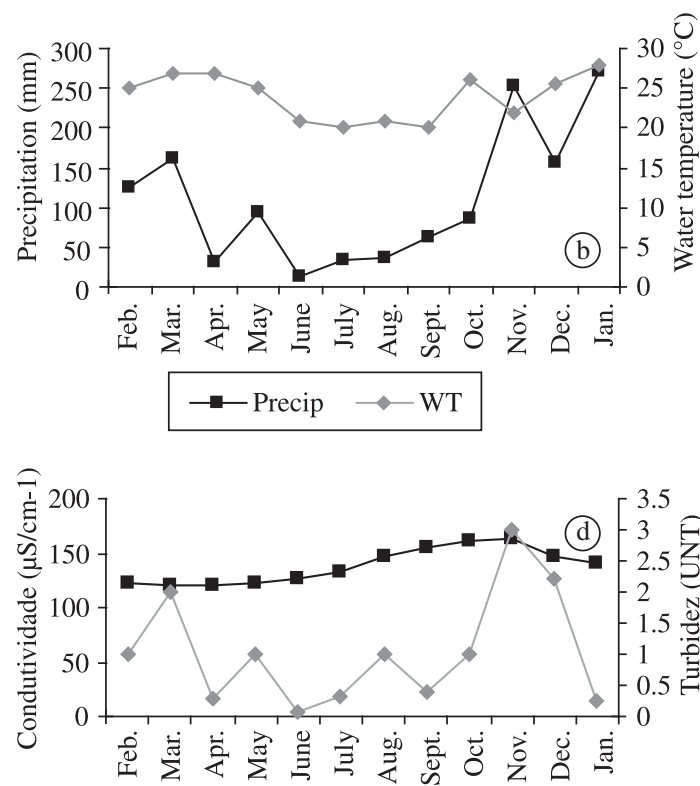

$\rightarrow-$ Cond $\multimap$ Turb

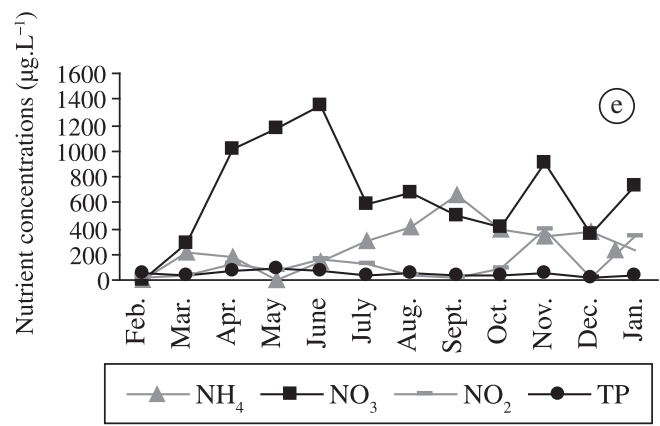

Figure 2. Monthly variation of physical and chemical parameters of Guarapiranga reservoir. Months are represented from February (Feb.) through December (Dec.) 2002 and January (Jan.) 2003. 

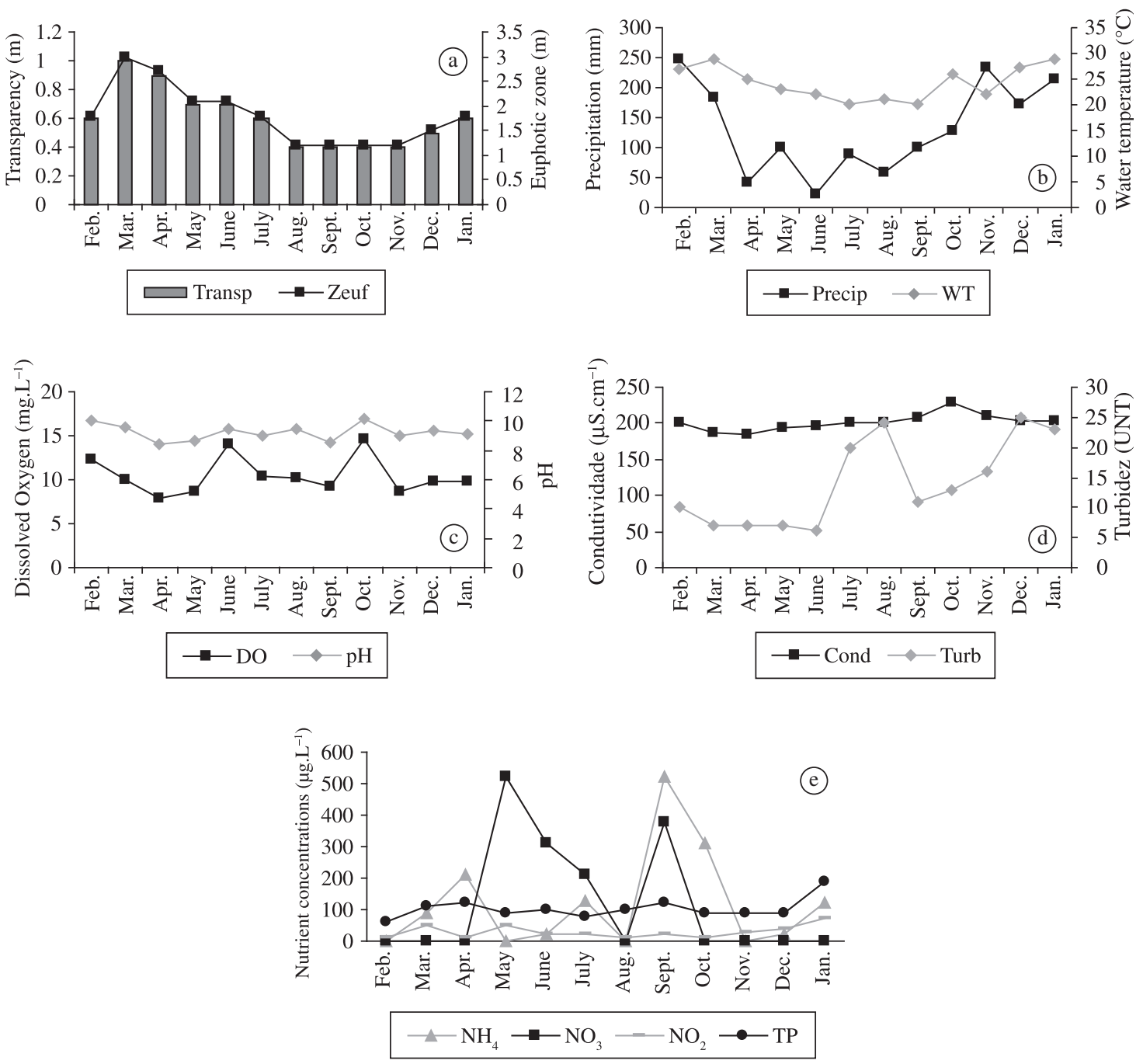

Figure 3. Monthly variation of physical and chemical parameters of Billings reservoir. Months are represented from February (Feb.) through December (Dec.) 2002 and January (Jan.) 2003.

Table 4. Pearson and Kendall correlation between environmental variables on the two first axes of the PCA ordination, as observed in the two reservoirs, during the period covered by the study $(n=24)$. In boldface they are the considered values, statistics, significant $(\mathrm{n} \geq 0.5)$.

\begin{tabular}{llrr}
\hline \multirow{2}{*}{$\begin{array}{c}\text { Environmental } \\
\text { variables }\end{array}$} & Abbreviations & \multicolumn{2}{c}{ Principal components } \\
\cline { 3 - 4 } & & 0.141 & Axis 2 \\
\hline Water temperature & $\mathrm{WT}$ & $\mathbf{- 0 . 9 5 7}$ \\
Transparency & Transp & $\mathbf{- 0 . 9 2 1}$ & -0.098 \\
Euphotic zone & Euphz & $\mathbf{- 0 . 9 1 5}$ & -0.112 \\
Turbidity & Turb & $\mathbf{0 . 7 8 5}$ & 0.113 \\
Conductivity & $\mathrm{Cond}$ & $\mathbf{0 . 8 7 3}$ & 0.218 \\
pH & $\mathrm{pH}$ & $\mathbf{0 . 8 6 6}$ & -0.178 \\
Dissolved oxygen & $\mathrm{DO}$ & $\mathbf{0 . 6 8 6}$ & 0.013 \\
Ammonium & $\mathrm{NH}_{4}{ }^{+}$ & -0.391 & 0.374 \\
Nitrate & $\mathrm{NO}_{3}^{-}$ & $\mathbf{- 0 . 7 8 8}$ & 0.130 \\
Nitrite & $\mathrm{NO}_{2}^{-}$ & $\mathbf{- 0 . 5 8 8}$ & -0.031 \\
Total phosphorus & $\mathrm{TP}^{-}$ & $\mathbf{0 . 5 9 5}$ & -0.065 \\
\hline
\end{tabular}




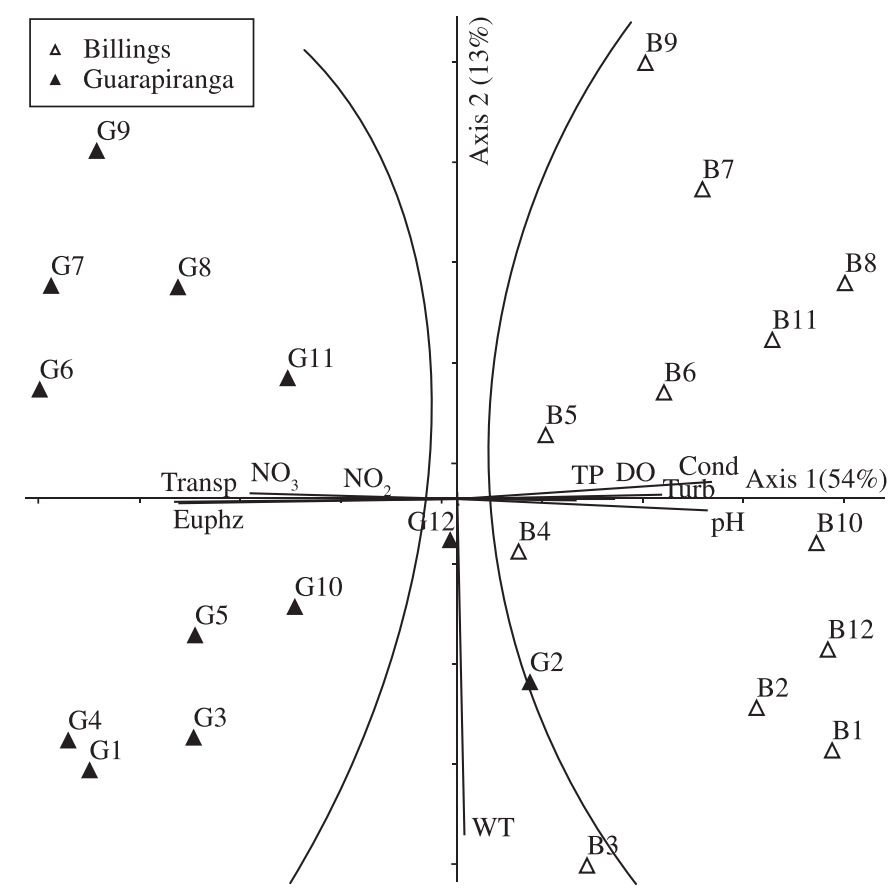

Figure 4. Biplot ordination resulting from the PCA applied to the sampling units (months) with the physical and chemical variables, in the Guarapiranga and Billings reservoirs. The initial G and B in the designation of sampling units stands for Guarapiranga and Billings reservoirs. Months are represented from February (G2/B2) throughout December (G12/B12) 2002, and January (G1/B1) 2003. Abbreviations for environmental variables are presented in Table 2.

separating the reservoirs, according to the environmental variables, as well as in a seasonal gradient tracking the axis 2: on the positive side the units referring to samples from Billings reservoir are shown, associated with the highest values of turbidity, conductivity, $\mathrm{pH}$, dissolved oxygen and total phosphorous. On the negative side appeared the sample units from Guarapiranga reservoir (except February/2002) associated with the highest values of transparency, euphotic zone, nitrate and nitrite. Axis 2 represented the seasonal changes, grouping on the positive side, the samples collected from winter and spring (June to November) and on the positive side, the samples collected from summer and autumn (December to April).

\subsection{Biological variables}

The number of taxa identified in Guarapiranga reservoir was 178 and in the Billings reservoir 156. Among them, 15 were selected as descriptors. The seasonal changes of the descriptor species is presented in Figure 5. Five functional groups were observed and in some cases co-dominance of species belonging to different groups at the same period was also observed. In Guarapiranga reservoir, $\mathrm{L}_{\mathrm{M}} / \mathrm{M}, \mathrm{H} 1$ and $\mathrm{T}$ groups were observed, in Billings reservoir, $\mathrm{L}_{\mathrm{M}} / \mathrm{M}, \mathrm{H} 1, \mathrm{~S} 1$ and $\mathrm{S}_{\mathrm{N}}$ groups were observed (Table 6).

\subsection{Guarapiranga reservoir}

The seasonal change was marked by two distinct periods. Period I: The month of February, character- ised by the highest biovolumes of Anabaena circinalis, Mycrocystis aeruginosa and Mougeotia sp., being this the period that showed the highest number of descriptor species, when the depth of the euphotic zone was below $1.8 \mathrm{~m}$ and nitrogen levels were zero. During period II, Mougeotia sp. was dominant from March to June (euphotic zone between 3.3 and $4.8 \mathrm{~m}$ and nitrate between 280 and 1,350 $\mu \mathrm{g} . \mathrm{L}^{-1}$ ) with a sudden decrease in July, due to factors that could not be detected in the present study. Period III: Mougeotia sp. was again dominant, from August to January (euphotic zone between 1.8 and $4.2 \mathrm{~m}$ and nitrate between 360 and $900 \mu \mathrm{g} . \mathrm{L}^{-1}$ ) (Figures 2 and 5a).

\subsection{Billings reservoir}

Descriptor species of the class Cyanobacteria were dominant throughout the period of study, but showed seasonal changes marked by three distinct periods: Period I from February through April, characterised by the highest biovolumes of Mycrocystis aeruginosa and $M$. panniformis and also by the highest values for the euphotic zone (1.8 to $3.0 \mathrm{~m}$ ). Period II (from April through September) was marked by the highest amount of descriptor species and high concentration of nitrogen. Period III: slow increase and dominance of Planktothrix agardhii, from period II to period III (euphotic zone between 1.2 and $1.8 \mathrm{~m}$ ). In the three periods high values of total phosphorous were observed (90 and $190 \mu \mathrm{g} . \mathrm{L}^{-1}$ ) (Figures 3 and 5b). 

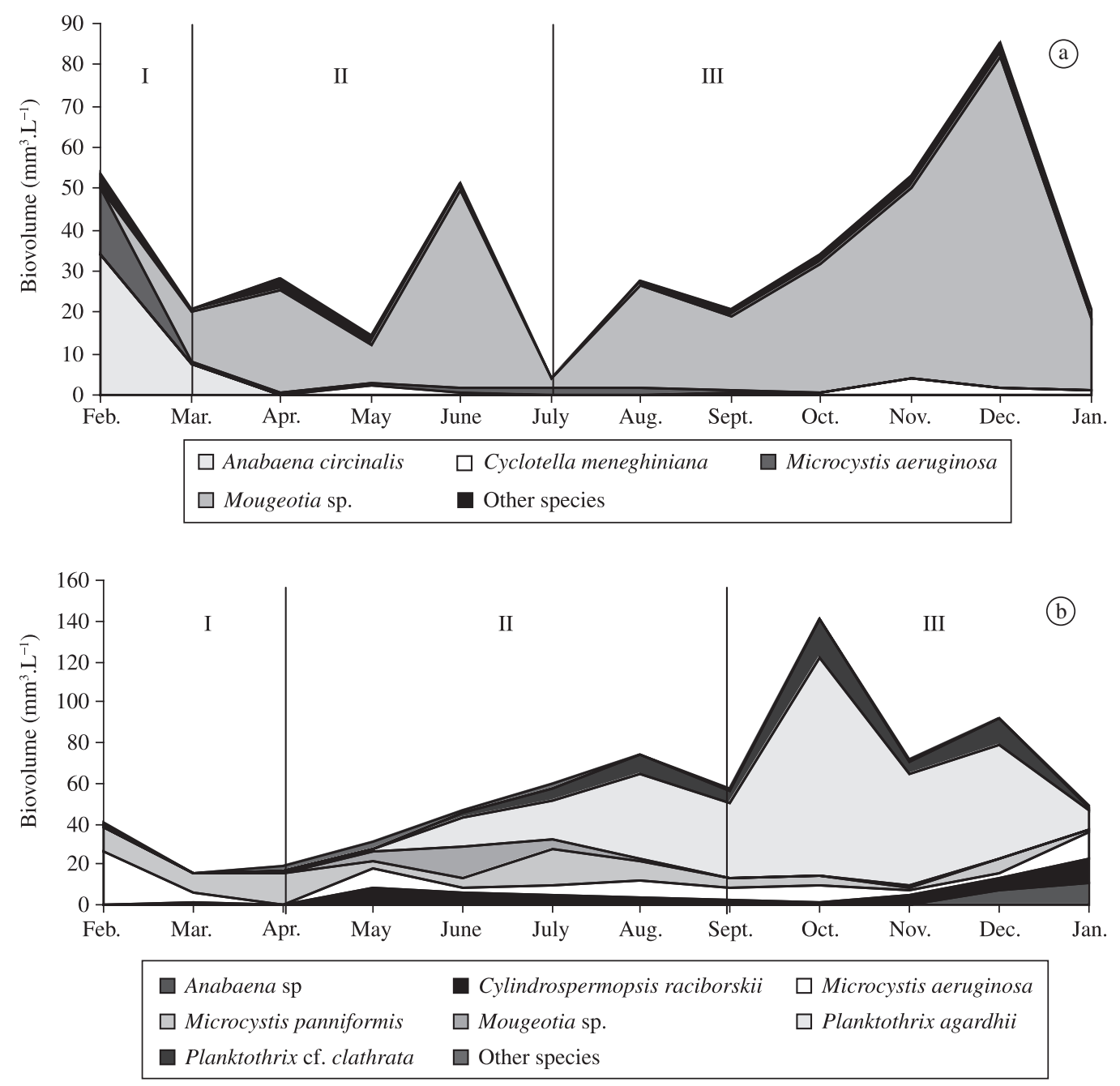

Figure 5. a) Biomass of the descriptor species in the Guarapiranga reservoir; other species: Golenkinia radiata, Limnothrix planctonica, Nitzschia gracilis, Scenedesmus quadricauda, Trachelomonas volvocina and b) Biomass of the descriptor species in the Billings reservoir; other species: Cyclotella meneghiniana, Geitlerinema unigranulatum, Trachelomonas volvocina. Months are represented from February (Feb.) through to December (Dec.) 2002 and January (Jan.) 2003.

To ordinate the sampling units between the reservoirs by means of the canonical correspondence analyses (CCA), fifteen species (those that contributed with more than $1 \%$ of the total biomass in the community) and eight environmental variables were selected (Tables 6 and 7). The autovalues for axes 1 and 2 were 0.459 and 0.125 , respectively, with $46.7 \%$ explicability of species variance for the two first axes (Table 5). Pearson's correlation for environment-species was high on both axes (0.917 and 0.972), indicating a high correlation between the abiotic variables and species distribution. The Monte Carlo test (99 permutations; $\mathrm{p} \leq 0.05$ ) was used to determine the canonic significance level, showing statistically significant and not random ordination of axes 1 and 2 $(\mathrm{p} \leq 0.05)$ (Table 5).

Canonic coefficient, that represents the importance of each environmental variable contribution, was used to ordinate and separate the two reservoirs. Intra-set correlation was also used to represent possible correlations between abiotic variables and their ordination with the axes, but retaining the dependency relation between the biotic and abiotic variables.

Canonic coefficient and intra-set correlation (Table 7) showed that turbidity, conductivity, $\mathrm{pH}$, dissolved oxygen and total phosphorous were the environmental variables best represented on axis 1 (positive side). The descriptor species that best correlated with this axis were: Cylindrospermopsis raciborskii, Microcystis aeruginosa, M. panniformis, Planktothrix agardhii and $P$. cf. clathrata. Axis 1 separated the sampling units according to the two reservoirs. The positive side of axis 1 contained the sampling units from Billings reservoir. These units are associated with the highest values of turbidity, conductivity, $\mathrm{pH}$, dissolved oxygen and 
Table 5. Synthesis of the Canonical Correspondence Analysis between the two reservoirs and the appraised months.

\begin{tabular}{lcc}
\hline & Axis 1 & Axis 2 \\
\hline Eigenvalue & 0.459 & 0.125 \\
\% of variance explained & 36.7 & 10.0 \\
Cumulative \% explained & 36.7 & 46.7 \\
Pearson Correlation (species-environment) & 0.917 & 0.972 \\
Monte Carlo test (p) eigenvalues & 0.01 & 0.03 \\
Correlation species-environment & 0.01 & 0.01 \\
\hline
\end{tabular}

Table 6. Descriptor species of the phytoplanktonic community, based on the contribution of percentage in biovolume (FG: Functional Groups; TB: Total Biovolume, in accordance with Reynolds et al., 2002).

\begin{tabular}{|c|c|c|c|}
\hline \multirow[t]{2}{*}{ FG } & \multirow[t]{2}{*}{ Descriptor species } & \multirow{2}{*}{$\begin{array}{c}\text { Guarapiranga } \\
\text { TB }(\%) \\
\end{array}$} & \multirow{2}{*}{$\begin{array}{l}\text { Billings } \\
\text { TB }(\%)\end{array}$} \\
\hline & & & \\
\hline H1 & Anabaena circinalis Rabenh. & 10.0 & - \\
\hline H1 (?) & Anabaena sp. & - & 2.0 \\
\hline A & Cyclotella meneghiniana Kützing & 2.0 & 1.0 \\
\hline $\mathrm{S}_{\mathrm{N}}$ & Cylindrospermopsis raciborskii (Wolosz.) Seen. and Subba Raju & 1.0 & 7.0 \\
\hline S1 ( & $\begin{array}{l}\text { Geitlerinema unigranulatum (Singh) Komárek and } \\
\text { M.T.P. Azevedo }\end{array}$ & - & 1.0 \\
\hline $\mathrm{J}$ & Golenkinia radiata Chodat & 1.0 & - \\
\hline S1 (?) & Limnothrix planctonica (Wolosz.) Meffert & 1.0 & - \\
\hline $\mathrm{L}_{\mathrm{M}} / \mathrm{M}(?)$ & Microcystis aeruginosa (Kützing) Kützing & 5.0 & 12.0 \\
\hline $\mathrm{L}_{\mathrm{M}} / \mathrm{M}(?)$ & M. panniformis Komárek et al. & - & 13.0 \\
\hline $\mathrm{T}$ & Mougeotia sp. & 73.0 & 4.0 \\
\hline $\mathrm{D}$ & Nitzschia gracilis Hantz. & 1.0 & - \\
\hline S1 & Planktothrix agardhii (Gom.) Anagn. and Komárek & - & 49.0 \\
\hline $\mathrm{S} 1(?)$ & P. cf. clathrata (Skuja) Anagn. and Komárek & - & 9.0 \\
\hline $\mathrm{J}(?)$ & Scenedesmus quadricauda (Turp.) Bréb. & 1.0 & - \\
\hline $\mathrm{W} 2$ & Trachelomonas volvocina Ehr. & 1.0 & 1.0 \\
\hline
\end{tabular}

(?) Species that are not included in the codes of functional groups, only referred to the genus.

Table 7. Canonical coefficient and intra-set correlation of environmental variables for axis 1 and 2 for ten abiotic variables in both reservoirs. In boldface they are the considered values, statistics, significant $(\mathrm{n} \geq 0.5)$.

\begin{tabular}{lcccc}
\hline Variable & \multicolumn{2}{c}{ Canonical coefficient } & & \multicolumn{2}{c}{ Correlation coefficient (intra-set) } \\
\cline { 2 - 3 } \cline { 2 - 3 } & Axis 1 & Axis 2 & Axis 1 & Axis 2 \\
\hline WT & -0.295 & -0.875 & 0.047 & $-\mathbf{0 . 5 6 9}$ \\
Euphz & 0.021 & 1.077 & -0.825 & 0.172 \\
Turb & -0.127 & -0.708 & $\mathbf{0 . 6 9 0}$ & -0.265 \\
Cond & 0.249 & 2.610 & $\mathbf{0 . 7 9 0}$ & 0.066 \\
pH & 1.075 & -1.605 & $\mathbf{0 . 8 5 5}$ & 0.099 \\
DO & -0.565 & 0.283 & $\mathbf{0 . 6 1 2}$ & 0.199 \\
N NO & -0.462 & -0.164 & $\mathbf{- 0 . 8 0 2}$ & 0.137 \\
TP & 0.501 & & $\mathbf{0 . 6 2 5}$ & -0.285 \\
\hline
\end{tabular}

total phosphorous. The negative side of axis 1 contained the sampling units of Guarapiranga reservoir, associated with the highest nitrate and euphotic zone values. The best represented species in those sampling units were:
Limnothrix planktonica, Desmodesmus communis and Mougeotia sp. Axis 1 has isolated only the sampling units of Billings reservoir, on the negative side. These units are associated with the highest values of water tem- 


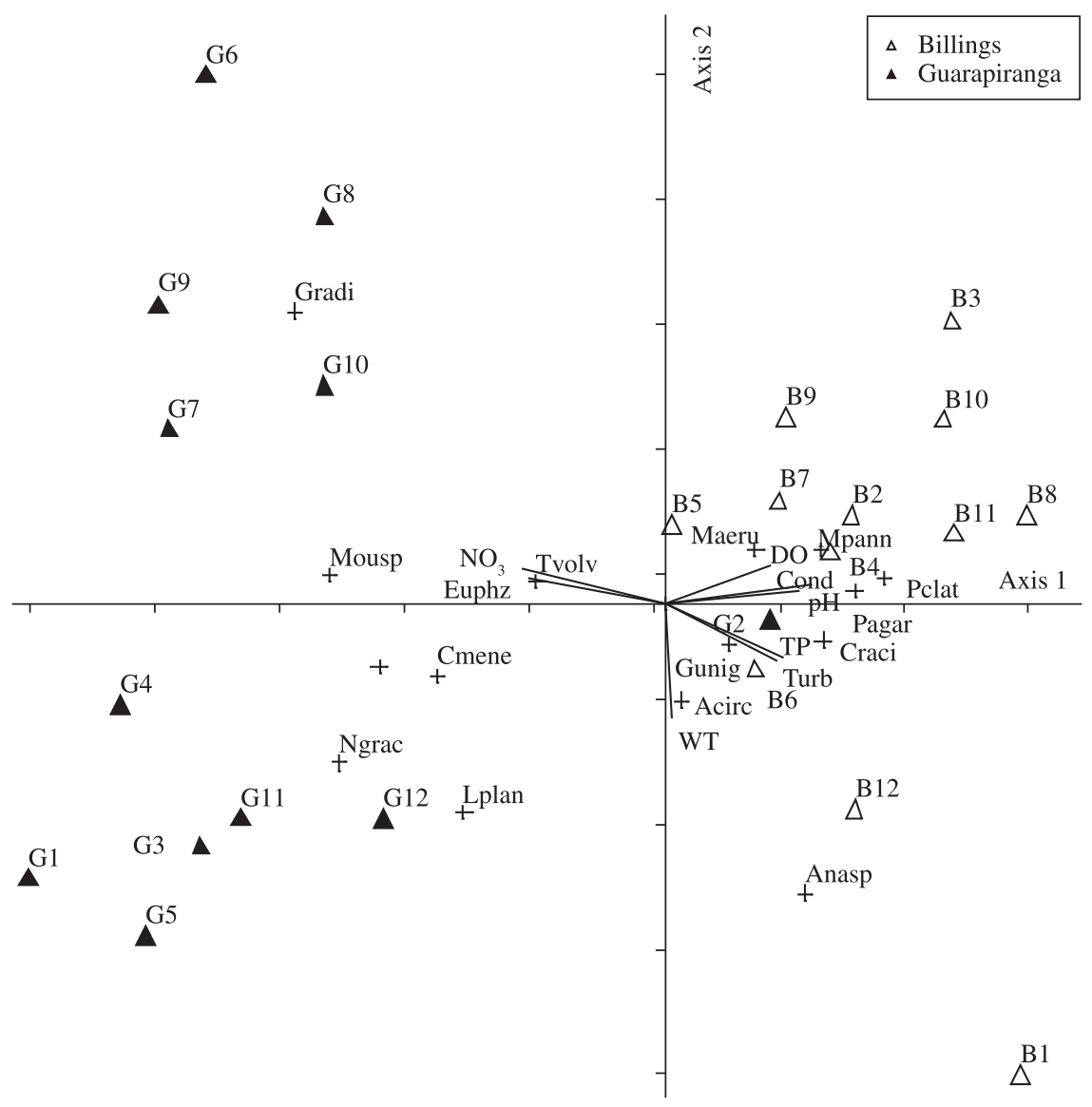

Figure 6. Biplot ordination resulting from the CCA to mean values of eight abiotic variables and fifteen biological variables in both reservoirs. The initial $\mathrm{G}$ and $\mathrm{B}$ in the designation of sampling units stands for Guarapiranga and Billings reservoirs. Months are represented from February (G2/B2) through to December (G12/B12) 2002, and January (G1/B1). Abbreviations: Anabaena circinalis (Acirc); Anabaena sp. (Anasp); Cyclotella meneghiniana (Cmene); Cylindrospermopsis raciborskii (Craci); Geitlerinema unigranulatum (Gunig); Golenkinia radiata (Gradi); Limnothrix planctonica (Lplan); Microcystis aeruginosa (Maeru); M. panniformis (Mpann); Mougeotia sp. (Mousp); Nitzschia gracilis (Ngrac); Planktothrix agardhii (Pagar); P. cf. clathrata (Pclat); Scenedesmus quadricauda (Squa) and Trachelomonas volvocina (Tvolv).

perature, and the best represented species were Anabaena circinalis and Anabaena sp. (Figure 6).

\section{Discussion}

The Principal Component Analysis (PCA) showed that the physical and chemical variables that interfered in the temporal reservoir dynamics were: water temperature, euphotic zone, turbidity, conductivity, $\mathrm{pH}$ and dissolved oxygen. Moreover, high nitrate and total phosphorus were available, allowing ideal conditions for phytoplankton blooms on both reservoirs. The PCA also confirmed the difference between the reservoirs, showed by their separation through axis 1 , also by a seasonal gradient through axis 2 .

\subsection{Guarapiranga reservoir}

The results confirmed high phytoplankton biomass, showing differences among months of the year, in relation to biomass and environmental parameters. The func- tional groups were grouped according to their monthly distribution, in the following periods:

I) The highest biovolume was represented by Anabaena circinalis (H1), Microcystis aeruginosa $\left(\mathrm{L}_{\mathrm{M}} / \mathrm{M}\right)$ and Mougeotia sp. $(\mathrm{T})$, when the lowest values for euphotic zone $(1.8 \mathrm{~m})$, low nitrate $\left(280 \mu \mathrm{g} . \mathrm{L}^{-1}\right)$ and high total phosphorus $\left(60 \mu \mathrm{g} . \mathrm{L}^{-1}\right)$ concentrations were recorded. The co-dominance of Microcystis and Mougeotia showed the opposite situation: in the first week of February the highest biovolume was shown by $M$. aeruginosa and in the fourth week, by Mougeotia sp. A. circinalis, the dominant species concerning biomass, also reduced its biovolume from the first to the last week of period I. These results show that the environmental conditions changed from the first to the fourth week, thus promoting the growth of Mougeotia sp. instead of the Cyanobacteria: gradual increase of transparency and euphotic zone, decrease of $\mathrm{pH}$ 
values, which may have supported higher $\mathrm{CO}_{2}$ than $\mathrm{CO}_{3}$ concentrations and increase in $\mathrm{N}-\mathrm{NO}_{3}$ availability;

II) A period where the complete dominance of Mougeotia sp. (T) began, lasting for about 16 weeks, combined with water temperature between $20-25{ }^{\circ} \mathrm{C}$, high euphotic zone (3.3-4.8 m) and high nitrate availability. In period II (July) there was a remarkable decrease of biovolume for all descriptor species, including Mougeotia sp., probably due to the decrease of nitrate concentration (from 1,350 to $580 \mu \mathrm{g} . \mathrm{L}^{-1}$ ), and management actions in the reservoir, that include the use of an algicide to prevent algal growth (Matsuzaki, 2007). However, the environmental conditions (water temperature, euphotic zone, conductivity, $\mathrm{pH}$ and total phosphorus) were much the same as in the former weeks, which allowed the restoring of the Mougeotia sp. population in period III; and

III) Continuity of Mougeotia sp. (T) dominance when the environmental conditions remained similar to those described for period II.

Beyruth (2000), studying the phytoplankton of Guarapiranga reservoir, has also found dominance of Mougeotia sp., correlating high biomass of the species to high rainfall, showing that this species, commonly peryphitic, has been detached from the littoral zone, thus appearing in the water column. Comparing these results to the present work, the rainfall was lower than that found by Beyruth (2000). However, higher biomass of Mougeotia sp. were found in period III (spring and summer), when the highest values for rainfall were found during the study. The research year period (2002) was atypical concerning rainfall, presenting monthly values below those found by Beyruth (2000), so it was assumed that, more than rainfall, the physical and chemical water characteristics were important, such as high nitrate concentration and high euphotic zone values (1.8-4.8 m).

According to Reynolds et al. (2002), Mougeotia sp. belongs to functional group $\mathrm{T}$, being sensitive to nutrient deficit and tolerant to low luminosity, which was demonstrated in the present study. Thus, it was concluded that Mougeotia sp. was considered as a meroplanktonic species, i.e., that has two ways (planktonic and peryphytic), so it is not an accidental species in this reservoir. Margalef (1983) mentions that when there are high numbers of small primary producers such as algae and Cyanobacteria that can be planktonic and also occur on some kind of substratum, or that occur in some undefined habitat between plankton and other, adhered, communities, they are ruled by light intensity and nutrient availability.

\subsection{Billings reservoir}

Cyanobacteria were dominant in this reservoir throughout the period of study. According to the dynamics of the functional groups, the period of study was divided into the following periods:
I) Period distinguished by the highest biovolume values of Microcystis aeruginosa and M. panniformis $\left(\mathrm{L}_{\mathrm{M}} / \mathrm{M}\right)$, water temperature between 25-29 ${ }^{\circ} \mathrm{C}$ and total phosphorus concentration between 60-120 $\mu \mathrm{g}$. $\mathrm{L}^{-1}$. Dominance was maintained by these two species throughout the period (eight weeks);

II) Period that lasted 20 weeks, when the water temperature varied from 20 to $25^{\circ} \mathrm{C}$, total phosphorus concentration between $80-120 \mu \mathrm{g} . \mathrm{L}^{-1}$, showing also the highest nitrate values, reaching $520 \mu \mathrm{g} . \mathrm{L}^{-1}$. During this period, there was the occurrence of the filamentous functional groups: Cylindrospermopsis raciborskii $\left(\mathrm{S}_{\mathrm{N}}\right)$, Planktothrix agardhii and $P$. cf clathrata (S1) and Mougeotia sp. (T), together with the species Microcystis aeruginosa and M. panniformis $\left(\mathrm{L}_{\mathrm{M}} / \mathrm{M}\right)$. The species that showed the highest biovolume was $P$. agardhii that increased in biovolume from the beginning to the end of period II, in a total of five months (20 weeks).

III) Gradual increase and dominance of P. agardhii, from period II to period III, water temperature from 20 to $29^{\circ} \mathrm{C}$ and total phosphorus between 90 and $190 \mu \mathrm{g} . \mathrm{L}^{-1}$.

The species of the functional groups $\mathrm{H} 1$ (Anabaena), $\mathrm{S}_{\mathrm{N}}$ (C. raciborskii), $\mathrm{L}_{\mathrm{M}} / \mathrm{M}$ (Microcystis) and $\mathrm{T}$ (Mougeotia) were poorly represented in relation to species S1 ( $P$. agardhii). The species belonging to functional groups $\mathrm{S} 1, \mathrm{H} 1$ and $\mathrm{S}_{\mathrm{N}}$ are often competing and in seasonal succession, due to their similar strategies. The occurrence of this succession depends mostly on inorganic nitrogen supply, disturbance pattern and sudden temperature change (Padisák et al., 2003).

According to Nixdorf et al. (2003), low light environments with high phosphorus values enhance the growth of species S1 (P. agardhii) due to the species ability to maintain itself in the water column that has high phosphorus concentration and high turbidity, often being permanent over the year as a monoculture. This fact can be observed in the present work, when $P$. agardhii was dominant throughout almost all the study period, showing that these environmental key factors favoured the dominance of these filamentous Cyanobacteria. The dominance of Oscillatoriales in temperate lakes, induced by the eutrophication process, has been noticed since the 1930s (Nixdorf et al., 2003).

An important factor to be considered in the Billings reservoir is the high water retention time (Table 1), enhancing the dominance of Cyanobacteria during the study period. The environmental stability explains the continuous dominance of one or few descriptor species, independently of its relation to one of these species to a particular physical condition (Huszar et al., 2003).

Considering both reservoirs, the species to one of the functional groups $\mathrm{H} 1$ (Anabaena) and $\mathrm{S}_{\mathrm{N}}$ (Cylindrospermopsis) tolerate environments with low nitrogen values, showing similar strategies and ability to atmospheric nitrogen fixation. In both reservoirs, 
the strategy of nitrogen fixation by heterocyted species seems not to have occurred, since no heterocyte was found in the sampled tricomae in the Guarapiranga reservoir. In the Billings reservoir, heterocytes were recorded only in $1.4 \%$ of $C$. raciborskii tricomae. The fact of few tricomae bearing heterocytes can be explained by high nitrogen concentration in the water bodies studied. Reynolds (1997), Padisák (1997) and Padisák and Reynolds (1998) explain that nitrogen fixing species H1 and $\mathrm{S}_{\mathrm{N}}$ (Anabaena and Cylindrospermopsis) can behave as non-fixing species due to a high nitrogen environment, this being also observed by Huszar et al. (2000) in eight Brazilian reservoirs. Thus, according to the results obtained in this study, it can be confirmed that the dominance of the functional groups $\mathrm{H} 1, \mathrm{~S}_{\mathrm{N}}, \mathrm{L}_{\mathrm{M}} / \mathrm{M}, \mathrm{T}$ and $\mathrm{S} 1$ are typical of different trophic levels (eutrophic to hypereutrophic) and can be used as environmental indicators in tropical regions. However species of the functional groups $\mathrm{L}_{\mathrm{M}}$ and $\mathrm{H} 1$ have also been reported as dominant in oligotrophic systems, this dominance being affected by seasonal variation of temperature, when thermal stratification occurs between the periods (Borges et al., 2008).

Besides, the Billings reservoir has also been exposed continuously to environmental degradation, due to nutrient input through waters pumped from the river Pinheiros and also to disordered occupation on the hydrological basin margins (Carvalho and Navas-Pereira, 2008). Thus, the results considered in the present study together with those of Carvalho and Navas-Pereira (2008) showed a situation of high trophic level state, identified not only by the presence of potentially toxic species but also by the trophic level, represented by the TSI. Considering the monthly biovolume values (from 15 to $140 \mathrm{~mm}^{3} \cdot \mathrm{L}^{-1}$ ) and total phosphorus (from 15 to $190 \mu \mathrm{g} . \mathrm{L}^{-1}$ ), the present study also revealed that both reservoirs can be classified as hypereutrophic (Brasil, 2004; Conama, 2005). In addition, the results for TSI, according to Lamparelli (2004) also corroborated the high trophic level for both reservoirs, since her proposal is specifically established for reservoirs of São Paulo state.

The poor condition of water quality could convert the Billings reservoir as inadequate to domestic supply, enhancing the costs of its treatment and the risks of its water consumption if the treatment was unsatisfactory (Carvalho and Navas-Pereira, 2008).

At present, the waters of a branch of Billings, called Taquacetuba, are pumped to Guarapiranga, as an additional contribution to the water supply for the Metropolitan Region of São Paulo, with high treatment costs, due to their poor quality (Carvalho and NavasPereira, 2008).

The results obtained herein showed that the optimal conditions for the development of the functional groups in Brazilian tropical conditions are: $\mathrm{pH}$ ranging between 7 and 9 , temperature between 20 and $30{ }^{\circ} \mathrm{C}$ and high levels of nutrients. The different strategies allowed the survival of these organisms leading to their rapid devel- opment, preventing the less fit species from growing. The physical and chemical factors frequently determine which species will prevail and dominate specific ecosystems (Matsuzaki et al., 2004).

Acknowledgements - The authors thank the Companhia de Tecnologia de Saneamento Ambiental (CETESB) for the phytoplankton samples and physical and chemical data; the Instituto de Botânica of S. Paulo for the use of laboratories and equipment; to Dr Andrea Tucci and Elvira C. Oliveira, BA, for the kind support in revising the manuscript. This work is part of the Water Quality Monitoring Program of the Drinking Water Resource Billings-Taquacetuba/Guarapiranga.

\section{References}

American Public Health Association - APHA. 1998. Standard methods for the examination of water and wastewater. 20 ed. Washington: APHA. 1268 p.

Associação Brasileira de Normas Técnicas - ABNT. 1988. NBR 10560. Brasília: ABNT. 897 p.

ARAUZO, M. and COBELAS, MA. 1994. Phytoplankton strategies and time scales in a eutrophic reservoir. Hydrobiologia, vol. 291, no. 1, p. 1-9.

BEYRUTH, Z. 2000. Periodic disturbances, trophic gradient and phytoplankton characteristics related to cyanobacterial growth in Guarapiranga Reservoir, São Paulo State, Brazil. Hydrobiologia, vol. 424, no. 1-3, p. 51-65.

BEYRUTH, Z., CALEFFI, S., ZANARDI, E., CARDOSO, E. and ROCHA, A. A. 1995. Water quality of Guarapiranga Reservoir 1991-1992, SP, Brazil. In XXVI Congress of the International Association of Theoretical and Applied Limnology. USA: Internationale Vereinigung für theoretische und angewandte Limnologie. vol. 26, p. 675-683.

BORGES, PAF., TRAIN, S. and RODRIGUES, LC. 2008. Spatial and temporal variation of phytoplankton in two subtropical Brazilian reservoirs. Hydrobiologia, vol. 607, p. 63-74.

BRASIL. SECRETARIA DE VIGILÂNCIA SANITÁRIA 2004. Portaria $n^{o} 518$, de 25 de Março de 2004. Estabelece os procedimentos e responsabilidades relativos ao controle e vigilância da qualidade da água para consumo humano e seu padrão de potabilidade. Brasília.

CALIJURI, MC. 1999. A comunidade fitoplanctônica em um reservatório tropical (Barra Bonita, SP). São Carlos: USP. $211 \mathrm{p}$.

CARLSON, RE. 1977. A trophic state índex for lakes. Limnology and Oceanography, vol. 2, no. 4. p. 361-380.

CARVALHO, MC. 2003. Comunidade fitoplanctônica como instrumento de biomonitoramento de reservatórios no estado de São Paulo. São Paulo: USP. 167 p. [Tese de Doutorado].

CARVALHO, MC. and NAVAS-PEREIRA, D. 2008. Uso da Comunidade Fitoplanctônica em Biomonitoramento de Reservatórios do Estado de São Paulo. In PHILIPPI JUNIOR, A., COLACIOPPO, S., MANCUSO, PCS. (Ed.). Temas de Saúde e Ambiente. São Paulo: Signus. 384 p.

Companhia de Tecnologia de Saneamento Ambiental CETESB. 1990. Determinação de pigmentos fotossintetizantes: 
clorofila-a, b e c e feofitina-a: método de ensaio. São Paulo: CETESB. p. 19. (Norma Técnica L 5.306)

Companhia de Tecnologia de Saneamento Ambiental - CETESB. 1997. Relatório de qualidade das águas interiores do Estado de São Paulo. São Paulo: CETESB. 289 p.

Companhia de Tecnologia de Saneamento Ambiental - CETESB. 2004. Relatório de qualidade das águas interiores do Estado de São Paulo. São Paulo: CETESB. vol. 2, 273 p.

COLE, G. 1994. Textbook of limnology. 4 ed. Illinois: Waveland Press Inc. 91 p.

Conselho Nacional de Meio Ambiente - CONAMA. Ministério do Meio Ambiente. 2005. Resolução $n^{\circ} 357$, de 17 de Março de 2005. Classificação dos corpos de água e diretrizes ambientais para o seu enquadramento, bem como estabelece as condições e padrões de lançamento de efluentes.

CROSSETTI, LO. and BICUDO, CEM. 2005. Structural and functional hytoplankton responses to nutrient impoverishment in mesocosms placed in a shallow eutrophic reservoir (Garças Pond), São Paulo, Brazil. Hydrobiologia, vol. 541, p. 71-85.

EDLER, L. (Ed.) 1979. Recommendation for marine biological studies in the Baltic Sea: phytoplankton and chlorophyll. Stockholm: National Swedish Environmental Protection Board. 38 p. (UNESCO, Working Group 11, Baltic Marine Biologists).

GRIME, J. 1979. Competition and the struggle for existence. In ANDERSON, RM., TURNER BD. and TAYLOR, LR. (Ed.). Population dynamics. 20 ed. Symposium of thebritsh Ecological Society. London: Blackwell Scientific Publication. 123-129.

HILLEBRAND, H., DÜRSELEN, CD., KIRSCHIEL, D., POLLINGHER, U. and ZOHARY, T. 1999. Biovolume calculation for pelagic and benthic microalgae. Journal of Phycology, vol. 35, no. 2, p. 403-424.

HUSZAR, VLM., SILVA, LH., MARINHO, M., DOMINGOS, P. and SANT'ANNA, C L. 2000. Cyanoprokaryote assemblages in eight productive tropical Brazilian waters. Hydrobiologia, vol. 424 , p. $67-77$

HUSZAR, VLM., KRUK, C. and CARACO, N. 2003. Steadystate assemblages of phytoplankton in four temperate lakes (NE U.S.A.). Hydrobiologia, vol. 502, p. 97-109.

KOMÁREK, J. and ANAGNOSTIDIS, K. 1989. Modern approach to the classification system of Cyanophytes 4: Nostocales. Algological Studies, vol. 56, p. 247-345.

KOMÁREK, J. and ANAGNOSTIDIS, K. 1999. Cyanoprokaryota, 1: Chroococcales In ETTL, H., GÄRTNER G., HEYNIG, H. and MÖLLENHAUER, D. (Ed.). Süßwasserflora von Mitteleuropa. Stuttgart: GustavFischer Verlag. vol. 19, no. 1, p. 548 p.

KOMÁREK, J. and ANAGNOSTIDIS, K. 2005. Cyanoprokaryota, 2: Oscillatoriales. In BÜDEL, B., KRIENITZ, L., GÄRTNER, G. and SCHAGERL, M. (Ed.). Süßwasserflora von Mitteleuropa. München: Elsevier GmbH. vol. 19, no. 2, $758 \mathrm{p}$.

KRUK, C., MAZZEO, N., LACEROT, G. and REYNOLDS, CS. 2002. Classification schemes for phytoplankton: a local validation of a functional approach to the analysis of species temporal replacement. Journal of Plankton Research, vol. 24, no. 9. p. 901-912.
LAMPARELLI, MC. 2004. Graus de trofia em corpos d'água do Estado de São Paulo: avaliação dos métodos de monitoramento. São Paulo: Instituto de Biociências da Universidade de São Paulo, USP. 235 p. [Tese de Doutorado].

LOPES, MRM., BICUDO, CEM. and FERRAGUT, MC. 2005. Short term spatial and temporal variation of phytoplankton in a shallow tropical oligotrophic reservoir, southeast Brasil. Hydrobiologia, vol. 542, p. 235-247.

MARGALEF, R. 1983. Limnologia. Barcelona: Omega. $1010 \mathrm{p}$.

MATSUZAKI, M. 2007. Transposição das águas do braço Taquacetuba da represa Billings para a represa Guarapiranga: aspectos relacionados à qualidade de água para abastecimento. São Paulo: Faculdade de Saúde Pública da Universidade de São Paulo, USP. 181 p. [Tese de Doutorado].

CARVALHO, MC. 2003. Comunidade fitoplanctônica como instrumento de biomonitoramento de reservatórios no estado de São Paulo. São Paulo: USP. 167 p. [Tese de Doutorado].

MATSUZAKI, M., MUCCI, JLN. and ROCHA, AA. 2004. Phytoplankton community in a recreational fishing lake, Brazil. Revista de Saúde Pública, vol. 38, no. 5, p. 679-686.

MCCUNE, B. and MEFFORD, MJ. 1997. PC-ORD multivariate analysis of ecological data. Version 3.0. Oregon: MjM Software Design. 47 p.

MELO, S. and HUSZAR, VLM. 2000. Phytoplankton in an Amazonian flood-plain lake (Lago Batata, Brasil): diel variation and species strategies. Journal of Plankton Research, vol. 22, no. 1 , p. $63-76$

NIXDORF, B., MISCHKE, U. and RÜCKER, J. 2003. Phytoplankton assemblages and steady state in deep and shallow eutrophic lakes - an approach to differentiate the habitat properties of Oscillatoriales. Hydrobiologia, vol. 502, p. $111-121$

PADISÁK, J., 1997. Cylindrospermopsis raciborskii (Woloszynska) Seenayya et Subba Raju, an espanding, highly adaptive cyanobacterium: worldwide distribution and review of its ecology. Archiv für Hydrobiologie., vol. 107, no. 4, p. $563-593$.

PADISÁK, J. and REYNOLDS, CS. 1998. Selection of phytoplankton association in Lake Balaton, Hungary, in response to eutrophication and restoration measures, with special reference to the cyanoprokaryontes. Hydrobiologia, vol. 384 , p. $41-53$

PADISÁK, J., BORICS, G., FEHÉR, G., GRIGORSZKY, I., OLDAL, I., SCHNIDT, A. and ZÁMBÓNÉ-DOMA, Z. 2003. Dominant species, functional assemblages and frequency of equilibrium phases in late summer phytoplankton assemblages in Hungarian small shallow lakes. Hydrobiologia, vol. 502, p. $157-168$.

PADISÁK, J., BORICS, G., GRIGORSZKY and SOROCZKIPINTER, I. 2006. Use of phytoplankton assemblages for monitoring ecological status of lakes the water framework directive: the assemblage index. Hydrobiologia, vol. 553, p. 1-14.

REYNOLDS, C. S. 1988. Functional morphology and adaptative strategies of freshwater phytoplankton. In ANDGREN, C. D. (Ed.). Growth and reproductive Strategies of freshwater Phytoplankton. Cambridge: Cambridge University Press. p. $388-433$. 
1997. Vegetation in the pelagic: a model for ecosystem theory. In KINNE, O. (Ed.). Excellence in Ecology. Germany: Ecology Institute. $371 \mathrm{p}$.

REYNOLDS, CS., HUSZAR, V., KRUK, C., NASELLIFLORES, L. and MELO, S. 2002. Towards a functional classification of the freshwater phytoplankton. Journal of Plankton Research, vol. 24, no. 5, p. 417-428.

SHEPHERD, GJ. 1986. Fitopac 1: manual do usuário. Campinas: UNICAMP. 95 p.

SOUZA, RCR., CARVALHO, MC. and TRUZZI, AC. 1998. Cylindrospermopsis raciborskii (Wolosz.) Seenaya and Subba Raju (Cyanophyceae) dominance and a contribution to the knowledge of Rio Pequeno arm, Billings reservoir, Brazil. Environmental Toxicology and Water Quality, vol. 13, p. 73-81.
TUCCI, A. 2002. Sucessão da comunidade fitoplactônica de um reservatório urbano e eutrófico, São Paulo, SP, Brasil. Rio Claro: UNESP. [Tese de Doutorado]. 274 p.

UTERMÖHL, H. 1958. Zur Vervollkommung der Quantitativen Phytoplankton-methodik. Verhandlungen Internationale Vereinigung für Theoretische und Angewandte Limnologie, vol. 9, p. 1-38.

Van Den HOEK, C., MANN, DG. and JAHNS, HM. (Ed.). 1995. Algae: an introduction to phycology. Cambridge: University Press. vol. 1, 627 p.

ZAGATTO, PA., ARAGÃO, MA., CARVALHO, MC. and SOUZA, RCR. 1997. Manual de orientação em casos de florações de algas tóxicas: um problema ambiental e de saúde pública. São Paulo: CETESB. vol. 14, p. 1-24. 